\title{
Lameness and lying behavior in grazing dairy cows
}

\author{
A. J. Thompson, ${ }^{1}$ D. M. Weary, ${ }^{1}$ J. A. Bran, ${ }^{2}$ R. R. Daros, ${ }^{1}$ M. J. Hötzel, ${ }^{2}$ and M. A. G. von Keyserlingk ${ }^{1 *}$ \\ ${ }^{1}$ Animal Welfare Program, Faculty of Land and Food Systems, The University of British Columbia, Vancouver, V6T 1Z4, Canada \\ 'Laboratório de Etologia Aplicada e Bem-Estar Animal, Departamento de Zootecnia e Desenvolvimento Rural, \\ Universidade Federal de Santa Catarina, Florianópolis, 88034-001, Brazil
}

\section{ABSTRACT}

Lameness is a serious welfare issue for dairy cows. To date, the majority of studies have focused on its effect on health and behavior at the herd level. The objectives of this study were to identify (1) between-cow and (2) within-cow changes in lying behavior associated with consistent and changing lameness status in grazing dairy cows. Previous studies of lying behavior in grazing dairy cows have not considered the effect of precipitation, so a third aim was to determine the effect of precipitation on lying behavior. A total of 252 dairy cows from 6 pasture-based farms in southern Brazil were gait scored weekly to assess lameness using a 5 -point scale [1-5, numerical rating score (NRS)] for 4 consecutive weeks. Cows were considered to have consistent lameness if they were scored as lame (NRS $\geq 3$ ) on each of the 4 visits and considered to have a changing lameness status if scored as being nonlame (NRS $<3)$ on at least 1 of the 4 visits. Cows classified as having a changing lameness status were further classified as developed, recovered, or inconsistent. Lying behavior (daily lying time, mean lying bout duration, and daily number of lying bouts) was recorded continuously for $3 \mathrm{wk}$ using leg-mounted accelerometers. Cow-level variables included parity, days in milk, and body condition score. Regional precipitation and temperature were recorded hourly. Because only 1 primiparous cow was identified as lame at each of the 4 visits, the between-cow analysis of lameness was run on multiparous cows only. The overall prevalence of clinical lameness on the first visit was $39 \%$, with development and recovery rates of 16 and $10 \%$ over the 4 visits, respectively. The betweencow effect of consistent lameness status on daily lying time and number of lying bouts was dependent on precipitation; consistently lame cows had reduced lying time and lying bouts on days with rain compared with days without rain. There was no within-cow effect of

Received September 18, 2018.

Accepted March 10, 2019.

*Corresponding author: marina.vonkeyserlingk@ubc.ca changing lameness status on any of the lying behaviors. Precipitation was associated with decreased daily lying time, increased mean lying bout duration, and decreased daily number of lying bouts. The results of this research provide the first evidence that the effect of consistent lameness status on lying behavior is associated with rainfall in grazing dairy cows. Future work measuring lying behavior of grazing dairy cows should include precipitation as a covariate.

Key words: gait, locomotion, precision farming, animal welfare

\section{INTRODUCTION}

Lameness is the manifestation of one or more claw, leg, or nerve pathologies that can cause standing and walking to be uncomfortable or painful (Whay et al., 1997, 1998); it is typically presented and diagnosed by an abnormal gait (e.g., score $1-5, \geq 3$ being clinically lame; Sprecher et al., 1997; Flower and Weary, 2006). In addition to compromising the welfare of individual animals, lameness has negative effects on the productivity and longevity of dairy cattle. Previous work has shown that lame cows have lower milk yield and reduced reproductive performance, and, in some cases, have an increased risk of being culled (reviewed by Huxley, 2013). Lameness is also one of the most expensive production diseases that affect dairy cattle (Kossaibati and Esslemont, 1997). Despite the negative impact, lameness remains common in many commercial pasture-based dairy farms, with prevalence ranging from 8 to 31\% (e.g., Fabian et al., 2014; Ranjbar et al., 2016; Bran et al., 2018).

Gait scoring is commonly used to identify lameness (Flower and Weary, 2009), with a variety of scoring systems used (e.g., Sprecher et al., 1997; Cook, 2003; Flower and Weary, 2006). Aside from changes in gait, lameness has also been shown to affect various behaviors in dairy cattle, such as lying (Ito et al., 2010; Sepúlveda-Varas et al., 2014; Weigele et al., 2018) and feeding (Weigele et al., 2018), which may serve as proxy measures for lameness detection. 
With increased automated recording of cow behavior (e.g., using wearable technology such as dataloggers), the use of these tools to explore the effects of lameness on behavior has gained popularity in research. The majority of research has focused on the relationship between lameness and daily lying time (Walker et al., 2008; Chapinal et al., 2010; Ito et al., 2010), as modulated by the number and duration of individual lying bouts (Ito et al., 2010; Sepúlveda-Varas et al., 2014). Most studies have measured the behavioral effects of lameness using cross-sectional studies, which only allow for between-group (i.e., lame versus nonlame) comparisons. To our knowledge, no research has investigated within-cow changes in lameness status and their effect on lying behavior.

A challenge in using changes in lying behavior to identify lameness is accounting for other factors that affect lying. In outdoor systems, cows might be especially affected by environmental factors such as rain. Experimental work has shown that indoors, dairy cows prefer to lie down on dry bedding (Fregonesi et al., 2007; Reich et al., 2010) and outdoors, dairy cows decrease daily lying duration when lying surfaces are wet (Tucker et al., 2007; Schütz et al., 2010; Chen et al., 2017); this response is thought to help reduce conductive heat loss, which is potentially more important in cooler temperatures (Tucker et al., 2007). At temperatures below freezing, when precipitation turns to snow, Graunke et al. (2011) found that the proportion of beef cows lying down increased compared with periods with similar temperatures and no snow. To date, no studies have quantified the effect of precipitation on the lying behavior of dairy cows managed at pasture.

This study had 3 main objectives: (1) to describe differences in lying behavior between lame cows and nonlame cows to test the prediction that lame cows would spend more time lying down; (2) to describe changes in lying behavior when nonlame cows become lame and vice versa, to test whether lying behaviors would change in relation to changing lameness status; and (3) to document the effects of precipitation on lying behavior. Consistent with previous findings with wet lying surfaces, we predicted that rainfall would decrease daily lying time.

\section{MATERIALS AND METHODS}

This study was approved by the University of British Columbia Animal Care Committee (A15-0082) and the Federal University of Santa Catarina Ethics Committee of Research on Animals (PP00949). Between June and August 2015, we evaluated 252 lactating dairy cows from 6 pasture-based dairy farms with rotational grazing located in the west of Santa Catarina, Bra- zil $\left(26^{\circ} 43^{\prime} 51^{\prime \prime} \mathrm{S}, 53^{\circ} 30^{\prime} 55^{\prime \prime} \mathrm{W}\right)$. The farms were part of a larger study focused on risk factors associated with lameness, metritis, and ketosis in lactating dairy cows managed on pasture (see Daros et al., 2017; Bran et al., 2018a,b). On each farm, cows were milked twice daily at approximately 0600 and $1600 \mathrm{~h}$ and were allowed access to supplemental silage and concentrate (an average of $21.3 \pm 10.1$ and $6.8 \pm 1.5 \mathrm{~kg} / \mathrm{cow}$ per day, respectively; means \pm SD) for approximately 30 min immediately after each milking. Both the milking and feeding areas had flat concrete flooring. Cows had access to pasture for the remainder of the day (a minimum of $16 \mathrm{~h} / \mathrm{d}$ ), under rotational grazing systems on paddocks of varying sizes. Pasture plant species consisted of primarily temperate grass species, such as oat (Avena sativa) and ryegrass (Lolium spp.), varying in age from juvenile to senescent. The use of trees to provide shade and shelter in the paddocks was minimal or absent.

\section{Data Collection}

Animal Measures. On the first farm visit, breed, parity, and DIM were retrieved from farm records or directly reported by the farmer. While cows were in the milking parlor, we assessed BCS (5-point scale with 0.25-point increments from 1 to 5 ; Ferguson et al., 1994). Data on milk yield per herd were obtained from dairy company records on the farm.

Gait Assessment. For 4 consecutive weeks, all lactating cows were gait scored by one of the researchers (J. A. Bran), a veterinarian with training in gait scoring. When cows exited the milking parlor and were walking along a straight, flat, hard surface, they were gait scored using a 5-point numerical rating score (NRS), where $1=$ nonlame and $5=$ severely lame (Flower and Weary, 2006). Cows were categorized as nonlame (NRS $\leq 2$ ), clinically lame (NRS $\geq 3$ ), or severely lame $(\mathrm{NRS} \geq 4)$. Because farms were visited just once a week, reliability of gait scoring was estimated using interrater reliability rather than intra-rater reliability. To determine inter-rater reliability, a second observer (A. J. Thompson), who was trained using video and livescoring, gait scored 48 lactating cows from one farm for each visit. The mean NRS values for each cow across all visits were used to generate intraclass correlation (ICC) estimates and their 95\% confidence intervals ( R version 3.4.3; R Core Team, 2017) based on single rater $(\mathrm{k}=2)$, consistency, and 2 -way random effects. The ICC estimate was 0.707 (95\% CI: $0.531-0.824 ; F_{(47,47)}$ $=5.82, P<0.001)$.

Lame cows were frequently treated using antibiotics and topical hoof products, whereas few were treated with anti-inflammatories or analgesics or hoof trimming as remedies (see Bran et al., 2018a). Farmers in 
this study did not have a systematic approach for diagnosing lameness or use regular preventative measures for lameness.

Lying Behavior. For 3 consecutive weeks, beginning immediately after the initial gait scoring session and ending immediately before the final gait scoring session, lying behavior was recorded at 1-min intervals using dataloggers (Hobo Pendant G, Onset Computer Corp., Bourne, MA) attached to the hind leg of each cow. Dataloggers were attached using a self-adherent bandage (Co-Flex, Andover Healthcare Inc., Salisbury, MA) and padded to minimize risk of chafing. Once a week, loggers were removed and replaced with new ones so that data could be downloaded. Standing or lying data were extracted following the methods outlined by Ledgerwood et al. (2010), using a 2-event filter to correct for bouts of standing or lying that lasted less than 3 min (UBC Animal Welfare Program, 2013).

Environmental Measures. This study took place between June and August, during the winter season in southern Brazil, a period when rain is frequent and temperatures are mild. Hourly regional temperature $\left({ }^{\circ} \mathrm{C}\right)$ and precipitation $(\mathrm{mm})$ were retrieved from the Automatic Meteorological Station in São Miguel do Oeste, Santa Catarina (National Institution of Meteorology, Ministry of Agriculture; $26^{\circ} 46^{\prime} \mathrm{S}, 53^{\circ} 30^{\prime} \mathrm{W}$ ). All farms were within $40 \mathrm{~km}$ of this weather station.

\section{Statistical Analysis}

Statistical analyses were performed in $\mathrm{R}$ (version 3.4.3; R Core Team, 2017) with linear mixed-effects models using $\mathrm{R}$ packages lme4 (Bates et al., 2015) and lmerTest (Kuznetsova et al., 2016). A $P$-value of $<0.05$ was considered statistically significant. Cows with incomplete datalogger recordings (missing more than 1 week, either because they were lost or stopped recording due to moisture) were not included in the analysis. Thus, data from 51 cows were excluded, leaving 201 cows in the final analyses.

Between-Cow Analysis: Consistent Lameness Status. This analysis included cows that were scored as nonlame (NRS $\leq 2$ ) or lame (NRS $\geq 3$ ) in each of the weekly gait scoring sessions over the 3 -wk study period. For these cows $(\mathrm{n}=103)$, daily lying time, mean lying bout duration, and the daily number of lying bouts were summarized individually.

Unconditional linear mixed-effects models with cow nested within farm as a random effect were used to screen the fixed effects of parity (categorical: primiparous and multiparous), DIM (continuous), BCS (continuous: 5 -point scale with 0.25 -point increments between 1 and 5 ), and total daily precipitation (continuous: $\mathrm{mm} / \mathrm{d}$ ), one variable at a time. Mean lying bout duration ( $\mathrm{min} /$ bout) and total daily precipitation $(\mathrm{mm} / \mathrm{d})$ were transformed using the ln function to better normalize their distributions. Variables with $P$-values $\leq 0.2$ were considered potential explanatory variables; precipitation, DIM, BCS, and parity were identified as potential explanatory variables. These variables were checked for collinearity with lameness status using unconditional logistic regression models with cow nested within farm as a random effect. Explanatory variables were considered collinear if the odds ratio was $>10$ (Dohoo et al., 2012). Parity was found to be highly collinear with lameness status (odds ratio $=55$ ), so the effect of lameness was considered separately for primiparous and multiparous cows. However, only 1 primiparous cow was classified as lame in our study, thus only the multiparous model was considered (nonlame: $\mathrm{n}=35$ cows; lame: $\mathrm{n}=32$ cows). For multiparous cows, a linear mixed-effects model including cow nested within farm as random effect was used to test for the main effect of lameness on each lying behavior. The effect of parity on lying behavior for nonlame cows was also considered (primiparous: $n$ $=24$; multiparous: $\mathrm{n}=35$ ). For nonlame cows, a linear mixed-effects model including cow nested within farm as a random effect was used to test for the main effect of parity on each lying behavior. Normality and homoscedasticity of model and random effect residuals were assessed graphically. All possible 2-way interactions were tested and reported if significant.

Within-Cow Analysis: Changing Lameness Status. All cows that did not have consistent lameness status were considered to have changing lameness status $(\mathrm{n}=98)$. Cows were considered to have developed lameness if their weekly gait score changed from nonlame (NRS $\leq 2)$ to clinically lame $(\mathrm{NRS} \geq 3)$ and remained clinically lame for the remainder of the observational period. Cows were considered to have recovered from lameness if their weekly gait score changed from clinically lame (NRS $\geq 3$ ) to nonlame (NRS $\leq 2$ ) and they remained nonlame for the remainder of the observational period. Cows were considered to have an inconsistent lameness status if their weekly lameness status was not consistent.

Only cows that developed or recovered from lameness on the first, second, or third visit were considered in final analyses $(\mathrm{n}=76)$. Cows that developed or recovered from lameness on the fourth and final visit to the farm were omitted from final analyses because lying data were unavailable following the final gait score $(\mathrm{n}=22)$. Daily lying time, mean lying bout duration, the daily number of lying bouts, and total daily precipitation for these cows were summarized by cow and day $[\mathrm{n}=1,340$ observations (76 cows with $18 \mathrm{~d}$ of observation each 
Table 1. The number of cows, prevalence of clinical and severe lameness, and percentage of cows that had consistent and changing lameness status on 6 farms in southern Brazil $(\mathrm{n}=201$ cows)

\begin{tabular}{|c|c|c|c|c|c|c|c|c|}
\hline Farm & $\begin{array}{l}\text { No. of } \\
\text { lactating } \\
\text { cows }^{1}\end{array}$ & $\begin{array}{c}\text { Prevalence } \\
\text { of clinical } \\
\text { lameness }{ }^{2}(\%)\end{array}$ & $\begin{array}{c}\text { Prevalence } \\
\text { of severe } \\
\text { lameness }^{2}(\%)\end{array}$ & \multicolumn{2}{|c|}{ Consistent lameness status } & \multicolumn{3}{|c|}{ Changing lameness status } \\
\hline 1 & 42 & 25.7 & 7.1 & 20.0 & 8.6 & 22.9 & 11.4 & 37.1 \\
\hline 2 & 35 & 44.0 & 20.0 & 48.0 & 16.0 & 0 & 12.0 & 24.0 \\
\hline 3 & 47 & 60.6 & 25.5 & 11.8 & 44.1 & 23.5 & 8.8 & 11.8 \\
\hline 4 & 29 & 30.8 & 6.9 & 34.6 & 11.5 & 23.1 & 7.7 & 23.1 \\
\hline
\end{tabular}

${ }^{1}$ Based on total number of cows surveyed (252 cows).

${ }^{2}$ Calculated using gait scores from the first visit to each farm.

$=1,368$ possible observations)]. Linear mixed-effects models including farm, cow, and week as random effects were used to test the main effect of lameness on each lying behavior for cows that changed lameness status.

\section{RESULTS}

\section{Animal Measures}

The average lactating herd size was $42 \pm 10$ cows ( \pm SD; range: $29-57$ cows) with $83.5 \%$ Holstein, $9.0 \%$ Jersey, and 7.5\% Holstein-Jersey crossbred cows. Across farms, mean parity was $2.6 \pm 1.4$ (range: $1-6$ ), mean DIM was $192 \pm 123 \mathrm{~d}$ (range: 7-737 d), mean BCS was $3.17 \pm 0.45$ (range: $2.25-4.50$ ), and estimated mean daily milk yield was $19.8 \pm 4.7 \mathrm{~L} / \mathrm{d}$ (range: $13-25 \mathrm{~L} / \mathrm{d}$ ) during the summer months.

\section{Environmental Measures}

The average daily temperature throughout this study was $18.1 \pm 4.6^{\circ} \mathrm{C}\left( \pm \mathrm{SD}\right.$; range: $\left.2.9-29.8^{\circ} \mathrm{C}\right)$. It rained for 31 of $70 \mathrm{~d}$ during the study (average rainfall $17.7 \pm$ $27.0 \mathrm{~mm} / \mathrm{d}$ with rain; range: $0.2-132.8 \mathrm{~mm} / \mathrm{d}$ ).

\section{Lameness}

At the first visit, the average prevalence of clinical lameness was $39.2 \%$ across the 6 farms (range:
25.7-60.6\%), including $11.4 \%$ severe lameness (range: 0-25.5\%). No cows were scored as NRS 5. In total, $32.2 \%$ of cows were never scored as lame, $18.9 \%$ of cows were consistently clinically lame, and $23.3 \%$ of cows were inconsistent in their lameness status throughout the study. The mean proportions of cows in each herd that developed and recovered from lameness were 15.5\% (range: 0-23.5\%) and 10.1\% (range: $6.1-14.6 \%$ ), respectively. Of the cows that recovered from lameness, $27.8 \%$ were scored as severely lame on at least one of the visits (see Table 1 ).

\section{Lying Behavior}

Overall, cows in this study had a mean daily lying time of $10.9 \pm 1.4 \mathrm{~h} / \mathrm{d}( \pm \mathrm{SD})$, a mean lying bout duration of $80.8 \pm 16.8 \mathrm{~min} /$ bout, and a mean daily number of lying bouts of $9.6 \pm 1.8$ bouts/d (Table 2).

\section{Between-Cow Results: Consistent Lameness Status}

Model outputs for the association between lameness and lying behavior in multiparous cows can be found in Table 3. Model outputs for the association between parity and lying behavior in nonlame cows can be found in Table 4.

Daily Lying Time. For nonlame and lame multiparous cows, there was an interaction between lameness

Table 2. The average lying behavior of primiparous cows $(\mathrm{n}=44)$, multiparous cows $(\mathrm{n}=139)$, and all cows considered together $(\mathrm{n}=201)$ across the 6 farms included in this study (mean $\pm \mathrm{SD}$ [range])

\begin{tabular}{lccc}
\hline Lying behavior & $\begin{array}{c}\text { Primiparous } \\
\text { cows }\end{array}$ & $\begin{array}{c}\text { Multiparous } \\
\text { cows }\end{array}$ & $\begin{array}{c}\text { All } \\
\text { cows }\end{array}$ \\
\hline Daily lying time (h/d) & $10.7 \pm 1.1$ & $10.8 \pm 1.6$ & $10.9 \pm 1.4$ \\
& {$[9.0-13.1]$} & {$[7.0-15.8]$} & {$[7.0-15.8]$} \\
Lying bout duration (min/bout) & $81.7 \pm 16.7$ & $78.6 \pm 15.9$ & $80.8 \pm 16.8$ \\
& {$[48.0-121.0]$} & {$[46.8-132.7]$} & {$[46.8-132.7]$} \\
Daily number of lying bouts (no./d) & $9.4 \pm 1.7$ & $9.7 \pm 1.8$ & $9.6 \pm 1.8$ \\
& {$[5.7-14.1]$} & {$[5.4-15.2]$} & {$[5.4-15.2]$} \\
\hline
\end{tabular}


Table 3. The effect of consistent lameness status (nonlame: $\mathrm{n}=35$; lame: $\mathrm{n}=32$ ) on the daily lying time (min/d), natural logarithm (ln) of mean lying bout duration (min/bout), and daily number of lying bouts (no./d) of multiparous cows modeled using linear mixed-effects models with cow nested within farm as random effects

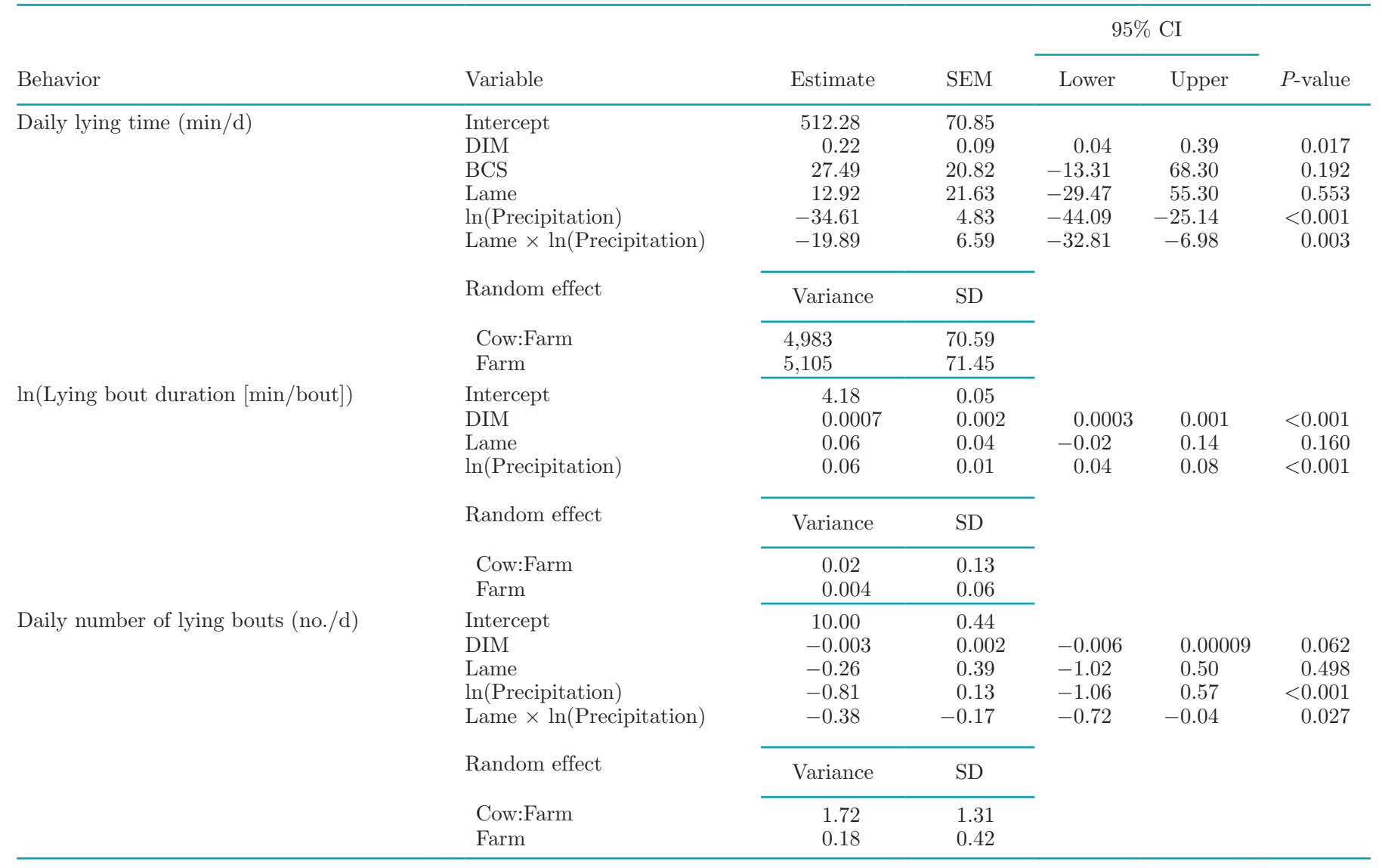

status and precipitation on daily lying time $(P=0.01)$. Overall, precipitation reduced total daily lying time; however, the magnitude of this change was dependent on lameness status: lame cows decreased their lying time more than nonlame cows on days with rainfall (Figure 1A). Similarly, for nonlame primiparous and multiparous cows, there was an interaction between the main effects of parity and precipitation on daily lying time $(P=0.003)$. Again, precipitation reduced daily lying time overall, but multiparous animals decreased their lying time less than primiparous animals on rainy days (Figure 2A).

Lying Bout Duration. For nonlame and lame multiparous cows, lameness status did not affect mean lying bout duration $(P=0.160)$ but precipitation increased mean lying bout duration regardless of lameness status $(P<0.001$; Figure 1B). Similarly, for nonlame primiparous and multiparous cows, parity did not affect mean lying bout duration $(P=0.432)$ but precipitation increased mean lying bout duration regardless of parity $(P<0.001 ;$ Figure 2B).
Number of Lying Bouts. For nonlame and lame multiparous cows, there was an interaction between the main effects of lameness and precipitation on number of lying bouts $(P<0.05)$. Overall, precipitation decreased lying bouts in both nonlame and lame cows $(P<0.001)$, but this effect was greater for lame cows (Figure 1C). For nonlame primiparous and multiparous cows, there was no effect of parity on the number of lying bouts $(P$ $=0.502)$, but precipitation decreased the number of lying bouts $(P<0.001$; Figure $2 \mathrm{C})$.

\section{Within-Cow Results: Changing Lameness Status}

There was no difference in daily lying time $(P=$ $0.11)$, mean lying bout duration $(P=0.986)$, or the daily number of lying bouts $(P=0.874)$ for cows that changed their lameness status (i.e., developed or recovered from lameness; Table 5). Precipitation was associated with decreased total daily lying time $(P<$ $0.001)$, increased mean bout duration $(P<0.001)$, and decreased daily number of lying bouts $(P<0.001)$. 
Table 4 . The effect of parity (primiparous: $\mathrm{n}=24$; multiparous: $\mathrm{n}=35)$ on the daily lying time $(\min / \mathrm{d})$, natural logarithm $(\mathrm{ln})$ of mean lying bout duration ( $\mathrm{min} /$ bout), and daily number of lying bouts (no./d) of nonlame cows modeled using linear mixed-effects models with cow nested within farm as random effects

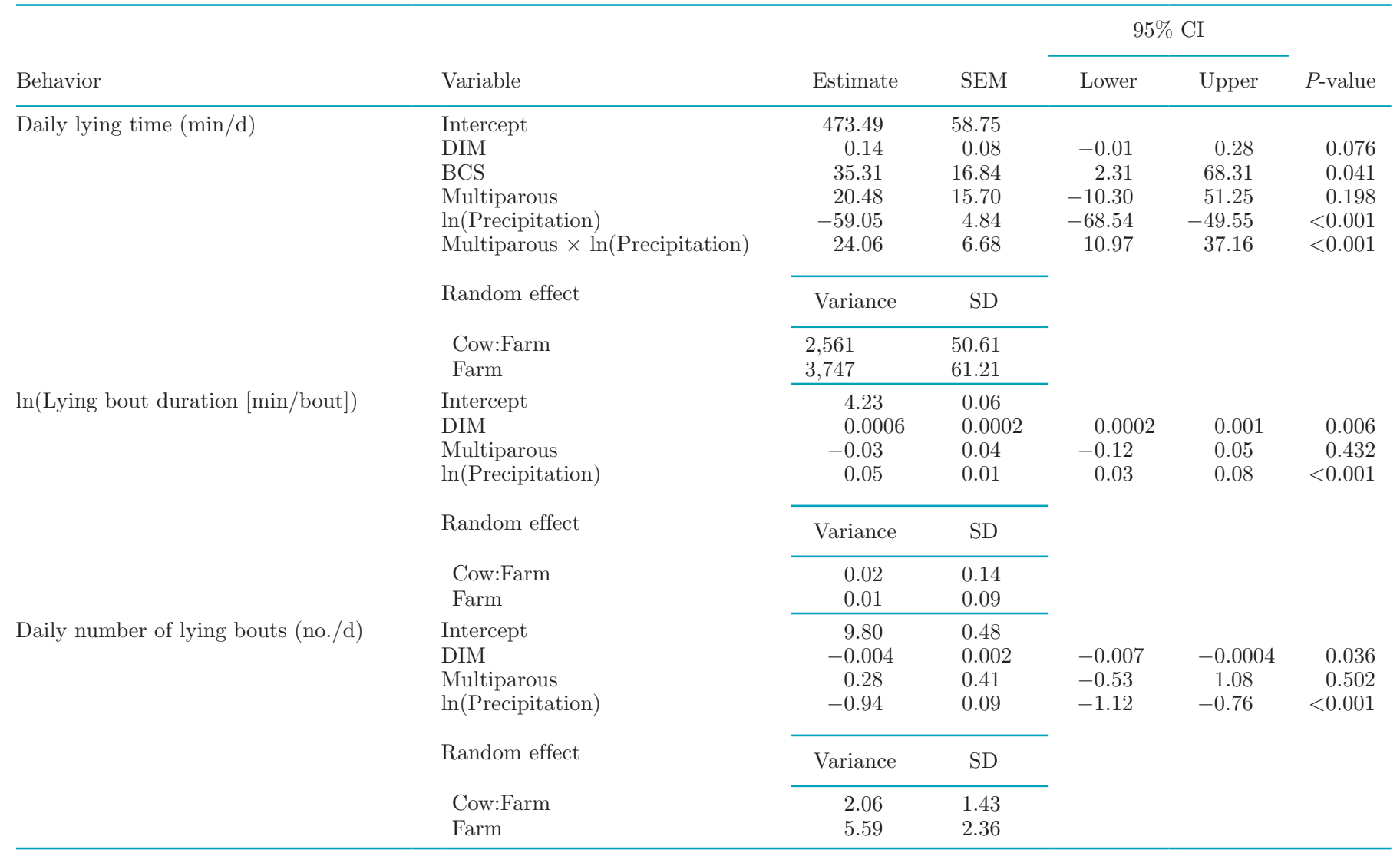

\section{DISCUSSION}

The daily lying time of cows in our study was similar to lying times reported in previous studies with grazing dairy cows (Krohn and Munksgaard, 1993; Legrand et al., 2009; Olmos et al., 2009; Sepúlveda-Varas et al., 2014), as well as to that of cows kept in loose-housed indoor systems with either automated milking systems (DeVries et al., 2011; Deming et al., 2013) or parlor milking systems (Wechsler et al., 2000; Ito et al., 2009). The daily number and duration of lying bouts reported here are similar to results reported previously for indoor-housed and outdoor-managed cows (Ito et al., 2010; Navarro et al., 2013; Weigele et al., 2018).

In contrast to previous findings, we did not detect a direct association between lameness status and lying time in this study (Navarro et al., 2013; SepúlvedaVaras et al., 2014). Previous cross-sectional studies have reported that lame cows spend an additional 24 to $126 \mathrm{~min} / \mathrm{d}$ lying down indoors (Ito et al., 2010; Navarro et al., 2013; Weigele et al., 2018) and an additional 91 to $105 \mathrm{~min} / \mathrm{d}$ lying down outdoors compared with nonlame cows (Walker et al., 2008; Navarro et al., 2013; Sepúlveda-Varas et al., 2014). Similarly, we did not detect a direct association between consistent lameness status and the number or duration of lying bouts. Other work has shown that lameness influences lying bouts, but the effect differs depending on both the severity of lameness and the type of lying surface (Ito et al., 2010; Sepúlveda-Varas et al., 2014; Weigele et al., 2018). To understand how lying bouts are affected by lameness in grazing systems, further research is needed to consider the quality of pasture as a lying surface.

To our knowledge, no previous research regarding lameness and lying behavior in grazing herds has accounted for precipitation (Olmos et al., 2009; Navarro et al., 2013; Sepúlveda-Varas et al., 2014). Our findings indicate that precipitation reduces lying time in cows regardless of lameness status, but the reduction in lying time is greater in lame cows. This decline in lying time was likely driven by lame cows reducing their number of lying bouts more than nonlame cows during periods of rainfall. Rain may also increase the chance that cows lie on wet, muddy, and slippery surfaces, which may in 

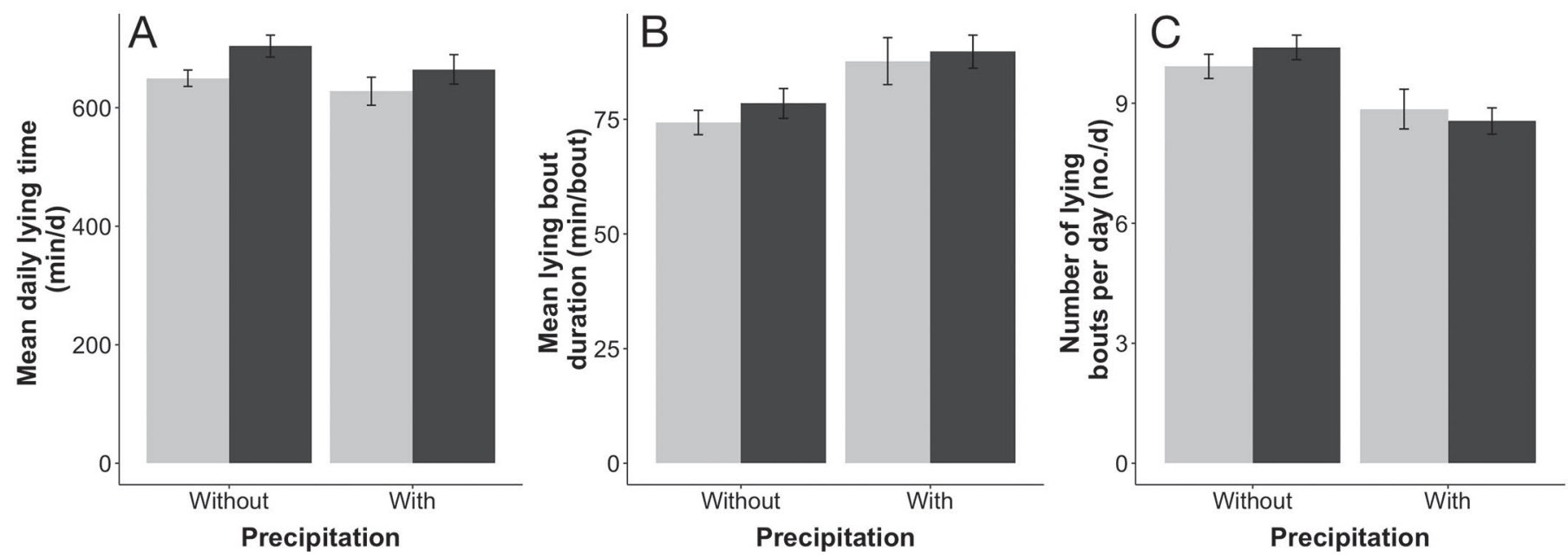

Figure 1. Bar plots showing consistent lameness status (light gray: nonlame; dark gray: lame) in relation to (A) mean daily lying time ( $\mathrm{min} / \mathrm{d})$, (B) mean lying bout duration (min/bout; untransformed), and (C) mean daily number of lying bouts (no./d) of multiparous cows on days with and without precipitation. Error bars represent \pm 1 SEM $(\mathrm{n}=67$ cows $)$.

turn compromise transitions from lying to standing and vice versa, perhaps especially affecting lame cows. Further research addressing how well lame and nonlame cows transition from lying to standing and vice versa is warranted.

Despite having similar average daily lying times, nonlame multiparous cows reduced their lying time less than nonlame primiparous cows on days with rain. This result is in contrast to previous work that reported greater reductions in lying time in dry cows than in heifers when exposed to a muddy lying surface (Chen et al., 2017). As mentioned above, multiparous cows may also be affected by wet, muddy, and slippery surfaces more than primiparous cows. Previous work has found that other behaviors (e.g., social and feeding behavior) differ between primiparous and multiparous cows (Neave et al., 2017). Unfortunately, we were not able to measure social or feeding behavior in this study. These mixed results suggest that more work is required to understand the effect of rain and wet lying surfaces on the lying behavior of grazing cows of different parities.

In contrast to our prediction, we did not find withincow differences in lying time or the number or duration of lying bouts associated with changes in lameness status (i.e., whether the same cow changed her lying behavior before and after being scored as lame). In our study,


Figure 2. Bar plots showing parity (light gray: primiparous; dark gray: multiparous) in relation to (A) mean daily lying time (min/d), (B) mean lying bout duration (min/bout; untransformed), and (C) mean daily number of lying bouts (no./d) of nonlame cows on days with and without precipitation. Error bars represent \pm 1 SEM $(n=59$ cows $)$. 
Table 5. The effect of changing lameness status (developed and recovered; $\mathrm{n}=30 \mathrm{cows}$ ) on the daily lying time (min/d), natural logarithm (ln) of mean lying bout duration (min/bout), and daily number of lying bouts (no./d) of grazing cows modeled using linear mixed-effects models with farm, cow, and week as random effects

\begin{tabular}{|c|c|c|c|c|c|c|}
\hline Behavior & Variable & Estimate & SEM & \multicolumn{2}{|c|}{$95 \%$ CI } & $P$-value \\
\hline \multirow[t]{2}{*}{ Daily lying time (min/d) } & $\begin{array}{l}\text { Intercept } \\
\text { Lameness status } \\
\ln \text { (Precipitation) }\end{array}$ & $\begin{array}{r}641.29 \\
-1.58 \\
-48.64\end{array}$ & $\begin{array}{r}25.63 \\
6.61 \\
2.84\end{array}$ & \multirow[t]{2}{*}{$\begin{array}{l}-14.55 \\
-54.21\end{array}$} & \multirow[t]{2}{*}{$\begin{array}{r}11.38 \\
-43.07\end{array}$} & \multirow[t]{2}{*}{$\begin{array}{r}0.811 \\
<0.001\end{array}$} \\
\hline & Random effect & Variance & $\mathrm{SD}$ & & & \\
\hline \multirow[t]{2}{*}{$\ln ($ Lying bout duration [min/bout] $)$} & $\begin{array}{l}\text { Intercept } \\
\text { Lameness status } \\
\ln \text { (Precipitation) }\end{array}$ & $\begin{array}{l}4.35 \\
0.0004 \\
0.05\end{array}$ & $\begin{array}{l}0.04 \\
0.02 \\
0.009\end{array}$ & \multirow[t]{2}{*}{$\begin{array}{r}-0.04 \\
0.03\end{array}$} & \multirow[t]{2}{*}{$\begin{array}{l}0.04 \\
0.06\end{array}$} & \multirow[t]{2}{*}{$\begin{array}{r}0.986 \\
<0.001\end{array}$} \\
\hline & Random effect & Variance & SD & & & \\
\hline \multirow[t]{3}{*}{ Daily number of lying bouts (no./d) } & $\begin{array}{l}\text { Intercept } \\
\text { Lameness status } \\
\ln \text { (Precipitation) }\end{array}$ & $\begin{array}{r}9.25 \\
0.03 \\
-0.94\end{array}$ & $\begin{array}{l}0.27 \\
0.18 \\
0.07\end{array}$ & \multirow[t]{3}{*}{$\begin{array}{l}-0.32 \\
-1.09\end{array}$} & \multirow[t]{3}{*}{$\begin{array}{r}0.37 \\
-0.80\end{array}$} & \multirow[t]{3}{*}{$\begin{array}{r}0.874 \\
<0.001\end{array}$} \\
\hline & Random effect & Variance & $\mathrm{SD}$ & & & \\
\hline & $\begin{array}{l}\text { Week:Cow:Farm } \\
\text { Cow:Farm } \\
\text { Farm }\end{array}$ & $\begin{array}{l}0.72 \\
2.34 \\
4.92\end{array}$ & $\begin{array}{l}0.85 \\
1.53 \\
0.4\end{array}$ & & & \\
\hline
\end{tabular}

cows were gait scored weekly, whereas lying behavior was recorded every minute and summarized daily. Thus, a cow's daily lying behavior may not have accurately reflected her most recent gait score if she changed her lameness status in the days following the most recent assessment. Furthermore, there may have been error in the weekly gait estimates; in this study, animals were live-scored, unlike in Flower and Weary (2006), when scorers had multiple opportunities to review video of each cow walking before scoring. Future research should consider including more frequent scoring for lameness, ideally daily, and for longer periods to allow for more meaningful comparisons between the lying behavior of the same individual when nonlame and lame. Identifying whether lying behavior changes before a change in gait would be an important first step. Furthermore, a greater number of cows should have been assessed to allow for a comparison of changes in lying behavior separately for cows that developed lameness and those that recovered from lameness. There may be differences in how lying behavior changes (e.g., magnitude and rate of change) for cows that develop and recover from lameness. We modeled developing and recovering lameness cases separately in previous analyses with no differences detected, likely due to the low number of animals in each category.

This study is the first to quantify the effect of precipitation on lying behavior in grazing dairy cows. Daily lying time decreased with rainfall, consistent with previous work that has shown reductions in daily lying duration associated with wet lying surfaces indoors (Fregonesi et al., 2007) and outdoors on wet dirt packs (Chen et al., 2017). Similarly, in agreement with the effect of muddy ground conditions found elsewhere (Chen et al., 2017), rainfall increased individual lying bout duration and decreased the number of lying bouts in this study. The results of this study show that precipitation is clearly an influential covariate with lying behavior in grazing dairy cattle.

The prevalence of lameness found in this study was similar to estimates previously reported for dairy cattle housed indoors (Cook et al., 2016; Solano et al., 2016; Adams et al., 2017; Costa et al., 2018) and at pasture (Olmos et al., 2009; Costa et al., 2013; Fabian et al., 2014; Ranjbar et al., 2016; Bran et al., 2018b). This research provides further evidence that lameness remains a pertinent issue in outdoor housing systems. We were able to measure the development of and recovery from 
lameness where no treatment for lameness was applied to the herds (for details, see Bran et al., 2018a, and Olmos et al., 2018). To our knowledge, no studies to date have reported incidence and cure rate in grazing cows; future studies should follow cows for longer periods to understand lameness dynamics in grazing systems.

\section{CONCLUSIONS}

Lame cows and nonlame cows differ in their lying behavior, thus lying time has the potential to be an effective indicator of lameness in grazing systems; however, more research is needed to identify key factors (e.g., precipitation) that also influence the lying behavior of cows at pasture. Given the strong effect of precipitation on lying behavior in this study, we recommend that future research include rainfall as a covariate when working with grazing cattle.

\section{ACKNOWLEDGMENTS}

We thank Melissa García (Laboratorio de Etologia Aplicada e Bem-Estar Animal at the Universidade Federal de Santa Catarina) and Guilherme V. Rodrigues (Laboratorio de Etologia Aplicada e Bem-Estar Animal at the Universidade Federal de Santa Catarina) for their help during this study. We also thank the farmers who voluntarily took part in this study. This research was supported by the Mitacs Globalink Research Award, facilitating international collaborative research between Maria J. Hötzel (Laboratório de Etologia Aplicada e Bem-Estar Animal at the Universidade Federal de Santa Catarina) and Marina A. G. von Keyserlingk (Animal Welfare Program at the University of British Columbia). This research was funded by the Science Without Borders Program (CNPq, National Council for Scientific and Technological Development, Brazil; grant no. 400850/2013-3), which also provided funds for M. A. G. von Keyserlingk to visit Brazil, which enabled this outstanding collaboration. Maria J. Hötzel received support from CNPq (grant no. 311509/2015$0)$. General support for the UBC Animal Welfare Program is provided by the Natural Sciences and Engineering Research Council's Industrial Research Chair Program, with industry contributions from the Dairy Farmers of Canada (Ottawa, ON, Canada), British Columbia Dairy Association (Burnaby, BC, Canada), Westgen Endowment Fund (Abbotsford, BC, Canada), Intervet Canada Corporation (Kirkland, QC, Canada), Novus International Inc. (Oakville, ON, Canada), Zoetis (Kirkland, QC, Canada), BC Cattle Industry Development Fund (Kamloops, BC, Canada), Alberta Milk (Edmonton, AB, Canada), Valacta (St. Anne-de-
Bellevue, QC, Canada), and CanWest DHI (Guelph, ON, Canada). J. A. Bran was supported by the Foundation for Research and Innovation of the State of Santa Catarina (FAPESC; Brazil).

\section{REFERENCES}

Adams, A. E., J. E. Lombard, C. P. Fossler, I. N. Román-Muñiz, and C. A. Kopral. 2017. Associations between housing and management practices and the prevalence of lameness, hock lesions, and thin cows on US dairy operations. J. Dairy Sci. 100:2119-2136.

Bates, D., M. Maechler, B. Bolker, and S. Walker. 2015. Fitting linear mixed-effects models using lme4. J. Stat. Softw. 67:1-48.

Bran, J. A., R. R. Daros, M. A. G. von Keyserlingk, and M. J. Hötzel. 2018a. Lameness on Brazilian pasture based dairies - Part 1: Farmers' awareness and actions. Prev. Vet. Med. 157:134-141.

Bran, J. A., R. R. Daros, M. A. G. von Keyserlingk, S. J. LeBlanc, and M. J. Hötzel. 2018b. Cow- and herd-level factors associated with lameness in small-scale grazing dairy herds in Brazil. Prev. Vet. Med. 151:79-86.

Chapinal, N., A. M. De Passillé, J. Rushen, and S. Wagner. 2010. Automated methods for detecting lameness and measuring analgesia in dairy cattle. J. Dairy Sci. 93:2007-2013.

Chen, J. M., C. L. Stull, D. N. Ledgerwood, and C. B. Tucker. 2017. Muddy conditions reduce hygiene and lying time in dairy cattle and increase time spent on concrete. J. Dairy Sci. 100:2090-2103.

Cook, N. B. 2003. Prevalence of lameness among dairy cattle in Wisconsin as a function of housing type and stall surface. J. Am. Vet. Med. Assoc. 223:1324-1328.

Cook, N. B., J. P. Hess, M. R. Foy, T. B. Bennett, and R. L. Brotzman. 2016. Management characteristics, lameness, and body injuries of dairy cattle housed in high-performance dairy herds in Wisconsin. J. Dairy Sci. 99:5879-5891.

Costa, J. H. C., T. A. Burnett, M. A. G. von Keyserlingk, and M. J. Hötzel. 2018. Prevalence of lameness and leg lesions of lactating dairy cows housed in southern Brazil: Effects of housing systems. J. Dairy Sci. 101:2395-2405.

Costa, J. H. C., M. J. Hötzel, C. Longo, and L. F. Balcão. 2013. A survey of management practices that influence production and welfare of dairy cattle on family farms in southern Brazil. J. Dairy Sci. 96:307-317.

Daros, R. R., M. J. Hötzel, J. A. Bran, S. J. LeBlanc, and M. A. G. von Keyserlingk. 2017. Prevalence and risk factors for transition period diseases in grazing dairy cows in Brazil. Prev. Vet. Med. 145:16-22.

Deming, J. A., R. Bergeron, K. E. Leslie, and T. J. DeVries. 2013. Associations of housing, management, milking activity, and standing and lying behavior of dairy cows milked in automatic systems. J. Dairy Sci. 96:344-351.

DeVries, T. J., J. A. Deming, J. Rodenburg, G. Seguin, K. E. Leslie, and H. W. Barkema. 2011. Association of standing and lying behavior patterns and incidence of intramammary infection in dairy cows milked with an automatic milking system. J. Dairy Sci. 94:3845-3855.

Dohoo, I., W. Martin, and H. Stryhn. 2012. Methods in Epidemiologic Research. 1st Ed. VER Inc., Charlottetown, Canada.

Fabian, J., R. A. Laven, and H. R. Whay. 2014. The prevalence of lameness on New Zealand dairy farms: A comparison of farmer estimate and locomotion scoring. Vet. J. 201:31-38.

Ferguson, J. D., D. T. Galligan, and N. Thomsen. 1994. Principal descriptors of body condition score in Holstein cows. J. Dairy Sci. 77:2695-2703.

Flower, F. C., and D. M. Weary. 2006. Effect of hoof pathologies on subjective assessments of dairy cow gait. J. Dairy Sci. 89:139-146.

Flower, F. C., and D. M. Weary. 2009. Gait assessment in dairy cattle. Animal 3:87-95.

Fregonesi, J. A., D. M. Veira, M. A. G. von Keyserlingk, and D. M. Weary. 2007. Effects of bedding quality on lying behavior of dairy cows. J. Dairy Sci. 90:5468-5472. 
Graunke, K. L., T. Schuster, and L. M. Lidfors. 2011. Influence of weather on the behaviour of outdoor-wintered beef cattle in Scandinavia. Livest. Sci. 136:247-255.

Huxley, J. N. 2013. Impact of lameness and claw lesions in cows on health and production. Livest. Sci. 156:64-70.

Ito, K., M. A. G. von Keyserlingk, S. LeBlanc, and D. M. Weary. 2010. Lying behavior as an indicator of lameness in dairy cows. J. Dairy Sci. 93:3553-3560.

Ito, K., D. M. Weary, and M. A. G. von Keyserlingk. 2009. Lying behavior: Assessing within- and between-herd variation in free-stallhoused dairy cows. J. Dairy Sci. 92:4412-4420.

Kossaibati, M. A., and R. J. Esslemont. 1997. The costs of production diseases in dairy herds in England. Vet. J. 154:41-51.

Krohn, C. C., and L. Munksgaard. 1993. Behavior of dairy cows kept in extensive (loose housing/pasture) or intensive (tie stall) environments II. Lying and lying-down behavior. Appl. Anim. Behav. Sci. $37: 1-16$.

Kuznetsova, A., P. B. Brockhoff, and R. H. B. Christensen. 2016 lmerTest: Tests in linear mixed effects models. https://CRAN.R -project.org/package $=$ lmerTest.

Ledgerwood, D. N., C. Winckler, and C. B. Tucker. 2010. Evaluation of data loggers, sampling intervals, and editing techniques for measuring the lying behavior of dairy cattle. J. Dairy Sci. 93:5129-5139.

Legrand, A. L., M. A. G. von Keyserlingk, and D. M. Weary. 2009. Preference and usage of pasture versus free-stall housing by lactating dairy cattle. J. Dairy Sci. 92:3651-3658.

Navarro, G., L. E. Green, and N. Tadich. 2013. Effect of lameness and lesion specific causes of lameness on time budgets of dairy cows at pasture and when housed. Vet. J. 197:788-793.

Neave, H. W., J. Lomb, M. A. G. von Keyserlingk, A. Behnam-Shabahang, and D. M. Weary. 2017. Parity differences in the behavior of transition dairy cows. J. Dairy Sci. 100:548-561.

Olmos, G., L. Boyle, A. Hanlon, J. Patton, J. J. Murphy, and J. F. Mee. 2009. Hoof disorders, locomotion ability and lying times of cubicle-housed compared to pasture-based dairy cows. Livest. Sci. 125:199-207.

Olmos, G., J. A. Bran, M. A. G. von Keyserlingk, and M. J. Hötzel 2018. Lameness on Brazilian pasture based dairies - Part 2: Conversations with farmers and dairy consultants. Prev. Vet. Med. 157:115-124

Ranjbar, S., A. Rabiee, A. Gunn, and J. House. 2016. Identifying risk factors associated with lameness in pasture-based dairy herds. J. Dairy Sci. 99:7495-7505.

R Core Team. 2017. R: A language and environment for statistical computing. R Foundation for Statistical Computing, Vienna, Austria. http://www.R-project.org/.
Reich, L. J., D. M. Weary, D. M. Veira, and M. von Keyserlingk. 2010 Effects of sawdust bedding dry matter on lying behavior of dairy cows: A dose-dependent response. J. Dairy Sci. 93:1561-1565.

Schütz, K. E., K. Clark, N. R. Cox, L. R. Matthews, and C. B. Tucker. 2010. Responses to short-term exposure to simulated rain and wind by dairy cattle. Anim. Welf. 19:375-383.

Sepúlveda-Varas, P., D. M. Weary, and M. A. G. von Keyserlingk. 2014. Lying behavior and postpartum health status in grazing dairy cows. J. Dairy Sci. 97:6334-6343.

Solano, L., H. W. Barkema, E. A. Pajor, S. Mason, S. J. LeBlanc, C. G. R. Nash, D. B. Haley, D. Pellerin, J. Rushen, A. M. de Passillé, E. Vasseur, and K. Orsel. 2016. Associations between lying behavior and lameness in Canadian Holstein-Friesian cows housed in freestall barns. J. Dairy Sci. 99:2086-2101.

Sprecher, D. J., D. E. Hostetler, and J. B. Kaneene. 1997. A lameness scoring system that uses posture and gait to predict dairy cattle reproductive performance. Theriogenology 47:1179-1187.

Tucker, C. B., A. R. Rogers, G. A. Verkerk, P. E. Kendall, J. R. Webster, and L. R. Matthews. 2007. Effects of shelter and body condition on the behaviour and physiology of dairy cattle in winter. Appl. Anim. Behav. Sci. 105:1-13.

UBC Animal Welfare Program. 2013. UBC Animal Welfare Program: SOP_HOBO Data Loggers. University of British Columbia, Vancouver, Canada. Accessed Aug. 8, 2016. http://lfs-awp.sites .olt.ubc.ca/files/2013/11/SOP-HOBO-Datalogger-november-2013 .pdf.

Walker, S. L., R. F. Smith, J. E. Routly, D. N. Jones, M. J. Morris, and H. Dobson. 2008. Lameness, activity time-budgets, and estrus expression in dairy cattle. J. Dairy Sci. 91:4552-4559.

Wechsler, B., J. Schaub, K. Friedli, and R. Hauser. 2000. Behaviour and leg injuries in dairy cows kept in cubicle systems with straw bedding or soft lying mats. Appl. Anim. Behav. Sci. 69:189-197.

Weigele, H. C., L. Gygax, A. Steiner, B. Wechsler, and J.-B. Burla 2018. Moderate lameness leads to marked behavioral changes in dairy cows. J. Dairy Sci. 101:2370-2382.

Whay, H. R., A. E. Waterman, and A. J. F. Webster. 1997. Associations between locomotion, claw lesions and nociceptive threshold in dairy heifers during the peri-partum period. Vet. J. 154:155-161.

Whay, H. R., A. E. Waterman, A. J. F. Webster, and J. K. O'Brien. 1998. The influence of lesion type on the duration of hyperalgesia associated with hindlimb lameness in dairy cattle. Vet. J. $156: 23-29$ 